\title{
Modal Sosial dan Dampaknya Pada Tata Kelola Tim Penggerak PKK Kelurahan di Kota Pekanbaru
}

\author{
NOVITA $^{1}$; KARTIKA SARI LUBIS ${ }^{2}$; YULIA HARWINA ${ }^{2}$ \\ 1,2,3 Sekolah Tinggi Ilmu Ekonomi Riau \\ Jln. HR Subrantas KM 12 No. 57 Panam Pekanbaru Telp. (0761) 63237 Fax. (0761) 63237 \\ E-mail : novita@lecturer.stieriau-akbar.ac.id
}

\begin{abstract}
Tujuan jangka panjang dalam rencana penelitian ini adalah model tata kelola tim penggerak PKK kelurahan di Kota Pekanbaru yang berbasiskan modal sosial yang dimiliki perempuan khusus ibu-ibu rumah tangga dengan berbagai kesibukannya mengurus rumah tangga. Kondisi ini dilatarbelakangi oleh pentingnya pemberdayaan perempuan dalam rangka memperkuat sumberdaya manusia melalui kelembagaan tim penggerak PKK. Selama ini tim penggerak PKK dalam aktivitasnya belum berjalan optimal seperti masalah keaktifan dalam berbagai kegiatan perempuan. Target khusus dari rencana penelitian ini adalah terpublikasinya hasil penelitian ini pada jurnal nasional tidak terakreditasi yakni pada jurnal daya saing sehingga dapat menjadikan bahan informasi dan sekaligus model yang dapat dipertimbangkan kepada pihak yang berkepentingan dalam mengembil keputusan tata kelola tim penggerak PKK. Metode yang digunakan dalam penelitian ini adalah metode survey, populasi dalam penelitian ini adalah ibu-ibu tim penggerak PKK (ketua, sekretaris dan bendahara) yang berjumlah 249 orang. Sedangkan sampel diambil sebanyak 72 orang dengan menggunakan rumus slovin dan data dikumpulkan dengan menggunakan kuesioner yang disusun berdasarkan operasionalisasi variabel modal sosial dan juga variabel tata kelola dan data yang diperoleh dianalisis dengan menggunakan regresi linier berganda melalui software SPSS versi 20. Hasil penelitian menunjukkan bahwa modal sosial berpengaruh signifikan terhadap tata kelola tim penggerak PKK Kelurahan di Kota Pekanbaru.
\end{abstract}

Keywords: Modal Sosial, Tata Kelola, Tim Penggerak PKK

Pemberdayaan perempuan menjadi amanah pada Negara sedang berkembang seperti Indonesia saat ini. Pemberdayaan perempuan sebagai mitra sejajar dengan laki-laki. Isu ini menjadi sangat meminta perhatian publik baik nasional maupun internasional. Namun sampai detik ini upaya yang dilakukan masih belum optimal. Perlu adanya usaha yang lebih menjawab persoalan optimalisasi pemberdayaan perempuan secara nyata di masyarakat. Menurut Fukuyama dalam Ahdiah (2014) berbagai jenis perantara atau kelembagaan sosial merupakan unsur dari modal sosial yang di miliki oleh suatu masyarakat, di samping sistem nilai, seperti etika sosial dan etika penghormatan sosial, etos kerja, saling percaya (trust), jaringan hubungan-hubungan sosial, sistem pembagian kerja secara seksual, dan unsurunsur kebudayaan lainnya.
Guna meningkatkan kualitas SDM perempuan Indonesia dan mewujudkan kemitrasejajaran antara laki-laki dan perempuan dalam kehidupan berkeluarga, bermasyarakat, berbangsa dan bernegara, pemerintah telah membentuk berbagai program dan sarana yang dapat membantu; salah satunya adalah organisasi Pemberdayaan dan Kesejahteraan Keluarga (PKK) di seluruh wilayah Indonesia. Organisasi ini telah diakui oleh masyarakat, bahkan pada tahun 2007 mendapat penghargaan dari beberapa lembaga internasional (WHO, Unicef, Unesco, dan sebagainya) karena melalui 10 program pokoknya PKK telah mampu melibatkan perempuan (dan lakilaki) dalam upaya mewujudkan keluarga yang sejahtera, maju dan mandiri. (Aslichati, 2015)

Perempuan mempunyai andil besar dalam membentuk sebuah keluarga yang 
bermartabat. Lebih dari itu, perempuan juga mempunyai andil besar dalam kegiatan penanggulangan kemis- kinan melalui pemberdayaan masyarakat dan kelompok yaitu dengan pendidikan dan keterampilan yang dimiliki. Untuk dapat membina keluarga secara langsung dan menjangkau sasaran sebanyak mungkin, maka dibentuk Gerakan Pemberdayaan dan Kesejahteraan Keluarga, yang mekanisme gerakannya dikelola dan dilaksanakan oleh suatu Tim Penggerak Pemberdayaan dan Kesejahteraan Keluarga (TP.PKK) di setiap jenjang. (Riana dan Sjamsudin, 2014)

Pekanbaru merupakan ibukota Propinsi Riau adalah salah satu daerah yang memiliki 83 kelurahan, dan 12 kecamatan yang tersebar, penyebaran ini memberikan gambaran mengenai keragaman masalah yang dihadapi di masyarakat. Apabila dilihat dari keilmuan manajemen, pada persoalan tim penggerak PKK, sebagai lembaga perempuan yang memiliki peran dalam kesejahteraan keluarga memang sepertinya masih jalan di tempat. Persoalan pengelolaan yang masih belum optimal, ditambah dengan persoalan yang lainnya berhubungan dengan masalah transparansi pengelolaan PKK, masalah kepedulian terhadap warga masyarakat yang menjadi sasaran PKK, dan program PKK terkesan hanya seremonial, hal ini menjadi pekerjaan rumah bagi pengurus PKK dan juga pemerintah Kota Pekanbaru dalam rangka menjadikan PKK efektif.

Pengurus PKK ini sangat penting dan bersifat strategis karena dalam memperdayakan keluarga sejahtera maju dan mandiri tidak terlepas dari peran seorang ibu. Melalui ibu-ibu PKK juga bisa diharapkan bisa mensinergikan program kerjanya dengan program pemerintah untuk memajukan dan mensejahterakan keluarga agar lebih maju dan mandiri. (http://www.pekanbaru.go.id/berita/beritapemko).

Pada satu sisi, perempuan menjadi basis SDM yang diharapkan mampu menggerakan PKK dan membuat PKK berhasil, namun selama ini terkesan belum berjalan sebagaimana mestinya, masih banyak persoalan keluarga yang belum terselesaikan, tetapi sesungguhnya ibu-ibu rumah tangga memiliki modal sosial yang baik dalam rangka menghidupkan gerakan tim PKK.

Oleh karenanya, penelitian ini diarahkan kepada bagaimana identifikasi modal sosial yang dimiliki oleh perempuan yang pada gilirannya dapat menjadikan pengelolaan PKK berhasil, yang akan diteliti dalam sebuah judul penelitian: Modal Sosial dan Dampaknya pada Tata Kelola Tim Penggerak PKK (Pemberdayaan Kesejahteraan Keluarga) Kelurahan di Kota Pekanbaru.

Menurut sejarahnya, PKK semula merupakan akronim dari Pendidikan Kesejahteraan Keluarga yang bertujuan untuk melibatkan partisipasi perempuan melalui program pendidikan perempuan. Kemudian, pada tanggal 27 Desember 1972 organisasi tersebut berubah nama menjadi Pembinaan Kesejahteraan Keluarga yang bertujuan untuk membina dan membangun keluarga di bidang mental, spiritual dan fisik serta peningkatan mutu pangan, sandang, kesehatan, dan lingkungan hidup. Anggotanya adalah tokoh/pemuka masyarakat, para isteri Kepala Dinas/Jawatan dan isteri Kepala Daerah sampai dengan tingkat Desa dan Kelurahan yang kegiatannya didukung dengan Anggaran Pendapatan dan Belanja Daerah. Selanjutnya dengan adanya reformasi serta paradigma baru dan semangat otonomi daerah, sejak tahun 1999 akronim PKK berubah lagi menjadi Pemberdayaan dan Kesejahteraan Keluarga. Kata pemberdayaan perempuan dipilih karena mengandung pengertian suatu usaha sistematis dan terencana untuk mencapai kesetaraan dan keadilan gender dalam kehidupan berkeluarga, bermasyarakat, berbangsa dan bernegara. Peningkatan kualitas perempuan melalui program pemberdayaan perempuan yang diarahkan untuk mengembangkan dan memanfaatkan 
berbagai potensi yang ada pada diri perempuan. (Aslichati, 2015)

Kesejahteraan keluarga menjadi tujuan utama PKK. Hal ini dikarenakan keluarga merupakan unit terkecil masyarakat yang akan berpengaruh besar terhadap kinerja pembangunan dalam mendukung program-program pemerintah. Dari keluarga yang sejahtera ini, maka tata kehidupan berbangsa dan bernegara akan dapat melahirkan ketentraman, keamanan, keharmonisan, dan kedamaian. Dengan demikian, kesejahteraan keluarga menjadi salah satu tolak ukur dan barometer dalam pembangunan dengan program-program pemerintah. (Shalfiah, 2017).

Berdasakan Keputusan Menteri Dalam Negeri dan Otonomi Daerah Nomor 53 tahun 2000 tentang Gerakan Pemberdayaan dan Kesejahteraan Keluarga, PKK mempunyai 10 program kerja yang merefleksikan kebutuhan dasar manusia Indonesia, yaitu:1) penghayatan dan pengamalan Pancasila, 2) gotong royong, 3) pangan, 4) sandang, 5) perumahan dan tatalaksana rumah tangga, 6) pendidikan dan keterampilan, 7) kesehatan, 8) pengembangan kehidupan berkoperasi, 9) kelestarian lingkungan hidup, 10) perencanaan sehat.(Aslichati, 2015)

Tata kelola kelembagaan menurut Syakhroza dalam Wibowo (2012) sebagai suatu mekanisme tata kelola organisasi secara baik dalam melakukan pengelolaan sumberdaya organisasi secara efisien, efektif, ekonomis ataupun produktif dengan prinsipprinsip terbuka, akuntabilitas, pertanggungjawaban, independen, dan adil dalam rangka mencapai tujuan organisasi. Tata kelola organisasi secara baik apakah dilihat dalam konteks mekanisme internal organisasi ataupun mekanisme eksternal organisasi. Mekanisme internal lebih fokus kepada bagaimana pimpinan suatu organisasi mengatur jalannya organisasi sesuai dengan prinsip-prinsip diatas sedangkan mekanisme eksternal lebih menekankan kepada bagaimana interaksi organisasi dengan pihak eksternal berjalan secara harmoni tanpa mengabaikan pencapaian tujuan organisasi.
Ashari (2010) Sedikitnya terdapat 3 (tiga) hal utama dalam melakukan pengelolaan atau penyelenggaraan pemerintahan/ birokrasi yang efektif dan efisien yaitu melakukan suatu langkah, upaya, ataukah perlakuan yang optimal dan merujuk kepada prinsip- prinsip tata kelola pemerintahan yang baik (good governance) terhadap kelembagaan (organisasi), ketatalaksanaan (business process), dan yang paling utama adalah sumberdaya manusia aparatur. Oleh karenanya, program reformasi birokrasi yang saat ini tengah gencar dilakukan, harus melibatkan atau mendasarkan prosesnya pada ketiga komponen utama tersebut diatas disamping faktor-faktor pendukung lainnya.

Governance merupakan suatu sistem, di mana yang mengoperasikannya adalah manusia, adapun kesuksesan penerapannya sangat bergantung pada integritas dan komitmen. Good Governance merupakan prinsip sangat universal, sehingga menjadi rujukan bagi semua umat beragama, serta dapat ditemukan pada kultur budaya di manapun. Hal yang membedakan praktik Good Governance di suatu negara adalah Good Governance sebagai sistem, karena harus selalu menyesuaikan dengan sistem hukum, keadaan dan perkembangan kemajuan, serta kultur bangsa itu sendiri. Didalam menerapkan governance yang baik, diperlukan pendekatan yang berbeda-beda, disesuaikan dengan keadaan dan waktu. (Wibowo, 2012)

Naping (2016) menjelaskan bahwa secara operasional kelembagaan lokal yang terdapat pada masing-masing kelompok masyarakat seperti telah diungkapkan, mengandung seperangkat nilai (value) dan norma (norms), dimiliki secara bersama oleh anggota masyarakat, berfungsi menata dan mengarahkan perilaku anggota masyarakat memenuhi suatu tujuan tertentu. Melalui sistem nilai dan sistem norma yang dimiliki masyarakat tercipta dan termanifestasikan sejumlah nilai dasar yang memungkinkan warga masyarakat melakukan aksi kolektif (colective action), 
saling membantu sehingga kebutuhan hidupnya, baik secara individual maupun secara kolektif dapat terpenuhi sehingga terhindar dari kefatalan hidup. Sejumlah nilai dan norma dalam kelembagaan lokal tersebut dipahami sebagai modal sosial (social capital).

Konsep modal sosial muncul dari pemikiran bahwa anggota masyarakat tidak mungkin dapat secara individu mengatasi berbagai masalah yang dihadapi. Diperlukan adanya kebersamaan dan kerjasama yang baik dari segenap anggota masyarakat yang berkepentingan untuk mengatasi masalah tersebut. Pemikiran seperti inilah yang pada awal abad ke 20 mengilhami seorang pendidik di Amerika Serikat bernama Lyda Judson Hanifan bahwa modal sosial bukanlah modal dalam arti biasa seperti harta kekayaan atau uang, tetapi lebih mengandung arti kiasan, namun merupakan aset atau modal nyata yang penting dalam hidup bermasyarakat. Menurut Hanifan dalam Syahra (2003), dalam modal sosial termasuk kemauan baik, rasa bersahabat, saling simpati, serta hubungan sosial dan kerjasama yang erat antara individu dan keluarga yang membentuk suatu kelompok sosial.

Sosiolog James Coleman dalam Ahdiah (2014) menyatakan bahwa modal sosial adalah "kemampuan masyarakat untuk bekerja bersama-sama demi mencapai tujuan bersama dalam berbagai kelompok dan organisasi“". Sejalan dengan itu terdapat juga konsep human capital yaitu kemampuan masyarakat untuk melakukan asosiasi (hubungan) satu sama lain.

Sementara itu, Wim van Oorschot dan Ellen Finsveen dalam Wijaya (2016) yang mengkaji mengenai social capital dan keterkaitannya dengan negara kesejahteraan mengkaitkan social capital terdiri dari 3 apek yaitu : (1) Jaringan Sosial; Hubungan dalam dan antara keluarga dan teman-teman (sosialisasi in- formal), keterlibatan dalam masyarakat dan kehidupan organisasi (misalnya sukarela), dan keterlibatan publik (misalnya pemilihan); (2) norma-norma sosial; nilai-nilai dalam masyarakat, norma dan kebiasaan kerjasama; dan kepercayaan sosial; Ke- percayaan pada lembaga sosial dan orang lain.

Otniel Pontoh (2010), masyarakat dengan karakter modal sosial terikat (social capital bonding). Tipologi modal sosial ini sangat dipengaruhi oleh nilainilai dan norma dari aspek ekonomi yang dimiliki dan dilakukan oleh masyarakat dalam kehidupan sehari-harinya. Hal ini berdampak pada struktur sosial yang terbentuk dalam kehidupan ekonomi masyarakat nelayan yang ada pada saat ini menjadi lebih berorientasi pada hubungan antar anggota dalam satu kelompok lebih banyak terfokus pada hal-hal yang terkait dengan aspek ekonomi. Hubungan antar kelompok di sisi lain sangat lemah, baik di dalam masyarakat maupun dengan pihak luar. mereka memiliki tipologi modal sosial terikat beserta penyebabnya menyiratkan perlunya kebijakan dalam rangka meningkat modal sosial di masyarakat nelayan tersebut. Kebijakan dimaksud adalah perbaikan struktur sosial yang terkait dengan kehidupan ekonomi masyarakat nelayan. Melalui kebijakan ini, diharapkan hubungan antar anggota dalam satu kelompok tidak hanya terfokus pada masalah ekonomis dan hubungan antar kelompok akan lebih terjalin kuat.

Radikawahyu Setyowati (2012), meneliti tentang Dampak Program Kelompok Pemberdayaan Dan Kesejahteraan Keluarga (Pkk) Terhadap Peningkatan Pemberdayaan Ekonomi Perempuan Di Dusun Sosoran Desa Candimulyo Kecamatan Kedu Kabupaten Temanggung. Diketahui bahwa 1) Dampak program kelompok PKK terhadap peningkatan kegiatan ekonomi menunjukkan dampak yaitu masyarakat dapat meningkatkan kegiatan ekonomi keluarga dengan mengikuti pelatihan keterampilan seperti pembuatan krupuk, molen pisang, membuka warung dan pembuatan mie basah yang diterapkan dikehidupan sehari-hari untuk meningkatkan pendapatan, 2) dampak program kelompok PKK terhadap peningkatan pendapatan ekonomi yaitu

p.ISSN: $2407-800 \mathrm{X} \quad$ e.ISSN: 2541-4356 
kenaikan tingkat penghasilan dari responden yang telah diwawancarai sebesar $4,77 \%$ 3) faktor pendukung dari program kelompok PKK adalah peran serta atau partisipasi dan minat dari anggota PKK yang cukup tinggi, motivasi dari pengurus kepada anggota PKK, 4) faktor penghambat dari program kelompok adalah tingkat pendidikan anggota yang ratarata masih rendah, sarana transportasi kurang memadahi dan perilaku anggota PKK yang kurang mengetahui apa itu organisasi PKK. Kata kunci: Pemberdayaan Perempuan, Kesejahteraan Masyarakat, Ekonomi

Trisakti Handayani, 2008, meneliti tentang Pemberdayaan Dan Kesejahteraan Keluarga (Pkk) Di Kota Malang: Dalam Perspektif Kajian Budaya. Hasil penelitian menunjukkan bahwa: (1) faktor-faktor yang mempengaruhi munculnya PKK adalah: politik, ekonomi, sosial dan budaya. Faktor ekonomi merupakan faktor paling berpengaruh pada awal kemunculan PKK, namun dalam perkembangannya faktor politik menjadi dominan karena terjadinya politisasi gerakan perempuan; (2) paradigma kelembagaan yang dikembangkan PKK adalah paradigma dari atas ke bawah (top down) dan bergerak dari konsep pendidikan, pembinaan, dan pemberdayaan; (3) makna PKK dikaitkan dengan kesetaraan dan keadilan gender, yaitu makna keharmonisan, makna solidaritas, makna keadilan, makna keselarasan, dan makna keseimbangan.

Lilik Aslichat (2012) meneliti dengan judul: Organisasi PKK Sebagai Salah Satu Sarana Pencapaian Millenium Development Goals Di Tingkat Akar Rumput. Kiprah PKK di lingkungan masyarakat juga merupakan salah satu ikon bergeraknya masyarakat madani dalam peningkatan kesejahteraan keluarga dan lebih terasakan efektivitasnya dengan adanya kader-kader yang menjangkau sampai di tingkat Desa/Kelurahan. Dengan kuatnya gerakan pemberdayaan keluarga di tingkat akar rumput, maka pelaksanaan pembangunan partisipatif dalam masyarakat akan mempunyai added-value yang signifikan.

\section{METODE}

Penelitian dilaksanakan di Kelurahan se Kota Pekanbaru dimana ruang lingkup pengumpulan data mencangkup pada seluruh tim penggerak PKK tingkat kelurahan. Pada penelitian ini yang menjadi objek/ peubah yang diamati, modal sosial, tata kelola kelembagaan tim penggerak PKK Kelurahan. populasi dalam penelitian ini adalah ibu-ibu tim penggerak PKK (ketua, sekretaris dan bendahara) yang berjumlah 249 orang. Sedangkan sampel diambil sebanyak 72 orang dengan menggunakan rumus slovin.

Data primer adalah data yang diperoleh dari pengamatan dan observasi secara angsung terhadap obyek yang diteliti melalui kuesioner. Dalam hal ini pengurus tim penggerak PKK Kelurahan yang diperoleh melalui kuesioner. Sedangkan data sekunder adalah data yang diperoleh dari instansi-instansi atau lembaga yang berkaitan dengan penelitian ini, misalnya studi literature terdahulu, studi kepustakaan, jurnal literatur-literatur yang berkaitan dengan permasalahan.

Analisa data dalam penelitian ini menggunakan metode deskriptif kuantatif yaitu suatu metode dengan mengelompokan data kedalam suatu distribusi frekuensi dan kemudian dianalisis dan dikaitkan dengan teori yang ada setelah itu baru dibuat suatu kesimpulan. Uji validitas dan uji reliabilitas serta uji normalitas dilakukan dalam penelitian ini untuk memastikan data normal dan juga layak digunakan dalam pengukuran statistic parametric.

Data analisis menggunakan metode regresi linier berganda. Untuk melihat persamaan umum regresi linier berganda dapat dilihat dengan metode ini. Analisis regresi berganda merupakan teknik analisis yang umum digunakan dalam menganalisis hubungan dan pengaruh satu variabel terikat (Y) dengan dua atau lebih variabel bebas $(\mathrm{X})$. apabila nilai variabel independen mengalami kenaikan atau penurunan dan untuk mengetahui arah hubungan antara variabel, apakah masing-masing ada hubungan positif atau negatif. 
Metode regresi linier berganda dapat dihitung dengan menggunakan:

$$
\mathrm{Y}=\alpha+\beta_{1} \mathrm{X}_{1}+\beta_{2} \mathrm{X}_{2}+\beta_{3} \mathrm{X}_{3}+\beta_{4} \mathrm{X}_{4}+\beta_{5} \mathrm{X}_{5}+\beta_{6} \mathrm{X}_{6}+\varepsilon
$$

Dimana :

$$
\begin{aligned}
& \mathrm{Y}=\text { Tata Kelola Tim Penggerak PKK } \\
& \quad \text { Kelurahan } \\
& \beta=\text { Koefisien Regresi } \\
& \mathrm{X}_{1}=\text { Kepercayaan } \\
& \mathrm{X}_{2}=\text { Saling pengertian } \\
& \mathrm{X}_{3}=\text { Nilai-nilai bersama } \\
& \mathrm{X}_{4}=\text { Keinginan mengikatkan diri } \\
& \mathrm{X}_{5}=\text { Perawatan } \\
& \mathrm{X}_{6}=\text { Sensitivitas } \\
& \alpha=\text { Konstanta } \\
& \varepsilon=\text { Variabel Error ( random error })
\end{aligned}
$$

\section{HASIL}

Berdasarkan hasil penelitian yang dilakukan berkaitan dengan modal sosial yang dimiliki oleh pengurus PKK yang terdiri dari enam modal sosial yang ada antara lain: kepercayaan, saling pengertian, nilai-nilai kebersamaan, keinginan untuk menigkatkan diri, perawatan dan sensitivitas. Dari keenam indikator modal sosial tersebut dikembangkan menjadi 18 item pertanyaan yang sebelumnya sudah dilakukan uji validitas dan reliabilitas.

Perhitungan dilakukan dengan menggunakan statistik deskriptif yakni dengan memberikan penilaian skor yang dikembangkan dari perkalian antar jawaban responden dengan nilai setiap jawaban dan dibagikan dengan jumlah sampel yang ada. Selain itu juga skor seterusnya akan diberikan penilaian dengan menggunakan range skor yakni: range 1-1,8 kategori tidak baik; range 1,8-2,6 kategori kurang baik; range 2,6-3,4 kategori cukup; range 3,4-4,2 kategori baik; range 4,2-5,0 kategori sangat baik.

Berikut deskripsi data variabel modal sosial yang dapat dipaparkan bahwa total skor modal sosial sebesar 4,2 yang masuk dalam kategori baik. Kemudian dapat dilihat dari enam indikator yang dimiliki dapat diketahui indikator tertinggi terletak pada indikator kepercayaan dan indikator terendah adalah pada keinginan meningkatkan diri.

\subsubsection{Tata kelola tim penggerak PKK Kelurahan di Kota Pekanbaru}

Tata kelola tim penggerak PKK menjadi variabel yang berkaitan dengan kepengurusan lembaga PKK yang merupakan kegiatan sosial masyarakat yang di program pemerintah dan ini telah dilaksanakan. Menggunakan skala tanggapan responden yang sama dengan uraian sebelumnya dan pada variabel tata kelola tim penggerak PKK Kelurahan dengan menyebarkan kuesioner kepada 72 orang pengurus PKK diperoleh bahwa total skor tata kelola lembaga PKK yang dikelola oleh tim penggerak PKK dengan skor sebesar 4,4 yang masuk dalam kategori sangat baik. Kemudian dapat dilihat dari lima indikator yang dimiliki dapat diketahui item tertinggi terletak pada hal pengambilan keputusan selalu pada kesepakatan dan item terendah adalah pada selalu melaporkan aktivitas dalam mengurus PKK sesuai dengan bidangnya.

Berdasarkan hasil perhitungan yang dilakukan dengan menggunakan alat analisis regresi linier berganda, digunakan software SPSS berkaitan perhitungan pengaruh variabel modal sosial yang terdiri dari kepercayaan, saling mengerti, nilainilai bersama, keinginan meningkatkan diri, perawatan dan sensitivitas terhadap tata kelola tim penggerak PKK Kelurahan di Kota Pekanbaru. Sebelumnya dilakukan uji validitas, uji reliabilitas dan uji normalitas data dan selanjutnya dilakukan perhitungan koefisien regresi, koefisien determinasi dan juga uji t serta uji $F$.

Uji validitas digunakan untuk melihat kelayakan kuesioner sebagai instrument penelitian untuk mengumpulkan data penelitian. Perhitungan dilakukan dengan menggunakan program SPSS melalui perhitungan nilai korelasi item dengan jumlah seluruh item. Untuk melihat validitatas dilihat dengan menggunakan standar $r$ hitung pada $n=72$ sebesar 0,23. Hasil perhitungannya dapat dilihat pada dapat diketahui seluruh nilai perhitungan

p.ISSN: 2407-800X e.ISSN: 2541-4356 
korelasi item lebih dibesar dibandingkan dengan $r$ tabel. Jadi seluruh item dinyatakan valid.

Perhitungan uji reliabilitas digunakan untuk melihat keajegan variabel dan dari hasil perhitungan dengan membandingkan nilai alpha setiap variabel dengan standar uji reliabilitas sebesar 0,6 dapat dilihat dapat dikatakan bahwa seluruh nilai alpha variabel lebih besar dibandingkan dengan nilai 0,60. Ini berarti bahwa seluruh variabel dinyatakan valid.

Uji normalitas digunakan sebagai syarat diterapkannya regresi berganda dalam penelitian ini, hasil perhitungan dapat menunjukkan mendekati garis diagonal, berarti bahwa data terdistribusi normal.

Perhitungan dengan analisis regresi linier berganda diperoleh data berkaitan dengan besarnya nilai pengaruh variabel modal sosial berupa kepercayaan, saling pengertian, nilai-nilai bersama, keinginan meningkatkan diri, perawatan dan juga sensitivitas terhadap tata kelola tim penggerak PKK Kelurahan Kota Pekanbaru bahwa nilai koefisien regresi dengan formulasi sebagai berikut:

$\mathrm{Y}=0,254+0,488 \mathrm{X} 1+0,221 \mathrm{X} 2+0,017 \mathrm{X} 3$ $+0,021 \mathrm{X} 4+0,448 \mathrm{X} 5+0,492 \mathrm{X} 6$

Keterangan:

1. Konstanta sebesar 0,254 yang berarti bahwa besarnya nilai tata kelola tim penggerak PKK Kelurahan dalam mengelola lembaga PKK bernilai 0,254 satuan pada saat $X$ sama dengan nol.

2. Koefisien regresi X1 sebesar 0,448 ini berarti bahwa variabel kepercayaan berpengaruh positif terhadap tata kelola tim penggerak PKK Kelurahan dalam mengelola lembaga PKK, yang mana semakin tinggi kepercayaan pengelola terhadap lembaga maka akan semakin baik tata kelola yang dikelola oleh pengurus.

3. Koefisien regresi X2 sebesar 0,221 ini berarti bahwa variabel saling pengertian berpengaruh positif terhadap tata kelola tim penggerak
PKK Kelurahan dalam mengelola lembaga PKK, yang mana semakin baik rasa saling pengertian sesame pengurus dalam mengelola lembaga maka akan semakin baik tata kelola yang dikelola oleh pengurus.

4. Koefisien regresi X3 sebesar 0,017 ini berarti bahwa variabel nilai-nilai bersama berpengaruh positif terhadap tata kelola tim penggerak PKK Kelurahan dalam mengelola lembaga PKK, yang mana semakin tinggi penerapan nilai-nilai bersama yang diyakini pengelola terhadap lembaga maka akan semakin baik tata kelola yang dikelola oleh pengurus.

5. Koefisien regresi $\mathrm{X} 4$ sebesar 0,021 ini berarti bahwa variabel keinginan meningkatkan diri berpengaruh positif terhadap tata kelola tim penggerak PKK Kelurahan dalam mengelola lembaga PKK, yang mana semakin tinggi tinggi keinginan memperbaiki diri pengelola terhadap lembaga maka akan semakin baik tata kelola yang dikelola oleh pengurus.

6. Koefisien regresi X5 sebesar 0,448 ini berarti bahwa variabel perawatan berpengaruh positif terhadap tata kelola tim penggerak PKK Kelurahan dalam mengelola lembaga PKK, yang mana semakin perawatan yang dilakukan pengelola terhadap lembaga maka akan semakin baik tata kelola yang dikelola oleh pengurus.

7. Koefisien regresi X6 sebesar 0,492 ini berarti bahwa variabel perawatan berpengaruh positif terhadap tata kelola tim penggerak PKK Kelurahan dalam mengelola lembaga PKK, yang mana semakin baik perawatan pengelola terhadap lembaga maka akan semakin baik tata kelola yang dikelola oleh pengurus.

Koefisien determinasi merupakan kontribusi variabel $\mathrm{X}$ terhadap variabel $\mathrm{Y}$, 
yang mana dapat diketahui dari sini variabel lain yang mempengaruhi tata kelola tim penggerak PKK dalam mengelola lembaga PKK Kelurahan tersebut. Berikut data berkaitan dengan nilai koefisien determinasi.

Berdasarkan hasil perhitungan diperoleh nilai koefisien determinasi sebesar 0,727 atau $72,7 \%$ pengaruh variabel modal sosial terhadap tata kelola tim penggerak PKK Kelurahan. Sedangkan sisanya sebesar $27,3 \%$ dipengaruhi oleh faktor lain yang tidak diteliti dalam penelitian ini.

Berdasarkan perhitungan $t$ hitung dengan memperlihatkan nilai $\mathrm{t}$ hitung dan kemudian juga nilai sign dan apabila nilai tersebut lebih besar dari 0,05 maka variabel yang diuji tidak berpengaruh signifikan. Namun apabila nilai sign lebih kecil dibandingkan dengan alpa 0,05 maka variabel yang uji memiliki pengaruh yang signifikan. bahwa varibael X1 (kepercayaan), Perawatan (X5) dan Sensitivitas (X6) memiliki nilai sign lebih kecil dari 0,05 ini berarti bahwa variabel tersebut berpengaruh signifikan terhadap tata kelola tim penggerak PKK Kelurahan dalam mengelola lembaga. Sedangkan variabel Saling Pengertian (X2), Nilai nilai bersama (X3) dan Keinginan meningkatkan diri (X4) memiliki nilai sign lebih besar dari 0,05 maka dapat dikatakan variabel tersebut tidak berpengaruh signfikan terhadap tata kelola tim penggerak PKK mengelola lembaga PKK Kelurahan. Variabel yang paling besar pengaruhnya adalah sensitivitas pengurus dalam mengurus lembaga PKK.

Uji F dilakukan untuk menguji secara simultan pengaruh variabel modal sosial terhadap tata kelola tim penggerak PKK, berikut ini data hasil olahan data SPSS dapat diketahui nilai $\mathrm{F}$ hitung sebesar 28.797 dengan sign sebesar 0,000 lebih kecil dari 0,05 maka dapat dikatakan bahwa secara simultan variabel modal sosial yang terdiri dari kepercayaan, saling pengertian, nilainilai bersama, keinginan meningkatkan diri, perawatan dan juga sensitivitas berpengaruh signifikan terhadap tata kelola tim penggerak PKK Kelurahan Kota Pekanbaru.

\section{PEMBAHASAN}

Lembaga PKK Kelurahan adalah lembaga ujung tombak pemberdayaan perempuan di Kota Pekanbaru. Lembaga ini bersinerji dengan pemerintah dalam rangka meningkatkan kesejahteraan masyarakat. Berdasarkan hasil penelitian dapat diketahui bahwa total skor modal sosial sebesar 4,2 yang masuk dalam kategori baik. Kemudian dapat dilihat dari enam indikator yang dimiliki dapat diketahui indikator tertinggi terletak pada indikator kepercayaan dan indikator terendah adalah pada keinginan meningkatkan diri.

Kemudian dilihat dari tata kelola lembaga PKK yang dikelola oleh tim penggerak PKK dengan skor sebesar 4,4 yang masuk dalam kategori sangat baik. Kemudian dapat dilihat dari lima indikator yang dimiliki dapat diketahui item tertinggi terletak pada hal pengambilan keputusan selalu pada kesepakatan dan item terendah adalah pada selalu melaporkan aktivitas dalam mengurus PKK sesuai dengan bidangnya.

Dari perhitungan yang dilakukan bahwa variabel modal sosial yang terdiri dari kepercayaan, saling pengertian, nilainilai bersama, keinginan meningkatkan diri, perawatan dan juga sensitivitas berpengaruh signifikan baik secara parsial maupun secara simultan terhadap tata kelola tim penggerak PKK Kelurahan Kota Pekanbaru. Variabel yang paling besar pengaruhnya adalah sensitivitas pengurus dalam mengurus lembaga PKK.

\section{SIMPULAN}

Dari hasil penelitian yang diperoleh maka dapat ditarik beberapa kesimpulan sebagai berikut: Variabel modal sosial sebesar 4,2 yang masuk dalam kategori baik. Kemudian dapat dilihat dari enam indikator yang dimiliki dapat diketahui indikator tertinggi terletak pada indikator kepercayaan dan indikator terendah adalah pada keinginan meningkatkan diri. Variabel tata kelola lembaga PKK yang dikelola oleh tim penggerak PKK dengan skor sebesar 4,4 yang masuk dalam kategori sangat baik. 
Kemudian dapat dilihat dari lima indikator yang dimiliki dapat diketahui item tertinggi terletak pada hal pengambilan keputusan selalu pada kesepakatan dan item terendah adalah pada selalu melaporkan aktivitas dalam mengurus PKK sesuai dengan bidangnya.

Dampak modal sosial yang terdiri dari kepercayaan, saling pengertian, nilainilai bersama, keinginan meningkatkan diri, perawatan dan juga sensitivitas berpengaruh signifikan baik secara parsial maupun secara simultan terhadap tata kelola tim penggerak PKK Kelurahan Kota Pekanbaru. Variabel yang paling besar pengaruhnya adalah sensitivitas pengurus dalam mengurus lembaga PKK.

\section{UCAPAN TERIMAKASIH}

Ucapan terima kasih yang sebesarbesarnya kepada Direktorat Riset dan Pengabdian Masyarakat, Direktorat Jenderal Penguatan Riset dan Pengembangan, yang telah memberikan dukungan dana dalam untuk penelitian ini sehingga menghasilkan informasi hasil penelitian yang dapat dimanfaatkan bagi kepentingan lembaga. Begitu pula kepada mahasiswa yang telah berpartisipasi dalam mengisi kuesioner penelitian ini.

\section{DAFTAR RUJUKAN}

Ahdiah, I. (2014). Organisasi Perempuan Sebagai Modal Sosial (Studi Kasus Organisasi Nasyiatul Aisyiyah Di Sulawesi Tengah). Academica, 3(1).

Ashari, E. T. (2010). Reformasi Pengelolaan SDM Aparatur, Prasyarat Tata Kelola Birokrasi yang Baik. Jurnal Borneo Administrator, 6(2).

Aslichati, L. (2012). Organisasi PKK Sebagai Salah Satu Sarana Pencapaian Millenium Development Goals (MDGs) di Tingkat Akar Rumput.
Aslichati, L. (2015). Organisasi Pemberdayaan dan Kesejahteraan Keluarga Sebagai Sarana Pemberdayaan Perempuan. Jurnal Organisasi dan Manajemen, 7(1), 1-7.

Handayani, T., Parimartha, M. A., Gde, I., Sukesi, M. S., Keppi, I. H., Ardika, M. A., \& Wayan, I. (2008). Pemberdayaan dan Kesejahteraan Keluarga (PKK) di kota Malang: dalam Perspektif kajian Budaya. E-Journal of Cultural Studies, 2(1).

http://www.pekanbaru.go.id/berita/beritapemko

Keputusan Menteri Dalam Negeri dan Otonomi Daerah Nomor 53 tahun 2000 tentang Gerakan Pemberdayaan dan Kesejahteraan Keluarga.

Naping, H. N. (2016). Modal Sosial Sebagai Strategi Pengentasan Kemiskinan Secara Mandiri Pada Desa Nelayan di Sulawesi Selatan dan Sulawesi Barat. SOCIUS: Jurnal Sosiologi, 12(1), 1-14.

Pontoh, O. (2010). Identifikasi Dan Analisis Modal Sosial Dalam Rangka Pemberdayaan Masyarakat Nelayan Desa Gangga Dua Kabupaten Minahasa Utara. Jurnal Perikanan dan Kelautan Tropis, 6(3), 125-133.

Riana, N. R. (2014). Pelaksanaan Peran Tim Penggerak Pemberdayaan dan Kesejahteraan Keluarga (PKK) dalam Memberdayakan Perempuan (Studi tentang Program Pendidikan dan Keterampilan di Kecamatan Kaliori Kabupaten Rembang). Jurnal Administrasi Publik, 2(5), 851-856. 
Riau dalam angka, 2016, Pekanbaru.

Setyoaji, R. (2012). Dampak Program

Kelompok Pemberdayaan Dan

Kesejahteraan Keluarga (Pkk)

Terhadap Peningkatan

Pemberdayaan Ekonomi Perempuan

Di Dusun Sosoran Desa

Candimulyo Kecamatan Kedu

Kabupaten Temanggung (Doctoral

dissertation, Fakultas Ilmu

Pendidikan, Universitas Negeri

yogyakarta).

Shalfiah, R. (2017). Peran Pemberdayaan

Dan Kesejahteraan Keluarga (Pkk)

Dalam Mendukung Program-

Program Pemerintah Kota

Bontang. Jurnal Universitas

Mulawarman, 1(3), 975-984.

Syahra, R. (2003). Modal sosial: Konsep dan aplikasi. Jurnal Masyarakat dan Budaya, 5(1), 1-22.

Wibowo, E. (2012). Implementasi Good Corporate Governance Di Indonesia. Ekonomi dan Kewirausahaan, 10(2).

Wijaya, A. A. M. (2016). Modal Sosial Untuk Kapasitas Community Governance (Studi Kasus Perempuan Pesisir Kelurahan Sulaa Kota Baubau). Jurnal Ilmu Pemerintahan, 1(1), 107-125. 